\title{
Effect of Organizational Culture on Individual Work Performance and Organizational Performance (Study at PT. Kramayudha Tiga Berlian Motors)
}

\author{
Pebri Tutur Srihadi ${ }^{1}$, Ferdinand Dehoutman Saragih ${ }^{2}$, Bernardus Yuliarto Nugroho ${ }^{3}$ \\ \{ptutursrihadi@gmail.com ${ }^{1}$, saragih_fds@yahoo.com ${ }^{2}$, nugroho_yuliarto@yahoo.com ${ }^{3}$ \} \\ ${ }^{1,2,3}$ Universitas Indonesia, Indonesia
}

\begin{abstract}
This study aims to see the influence of culture on individual performance and organizational performance which conducted in one of automotive company in Indonesia. This study discusses the difference between latent (exogenous) organizational culture variables towards latent (endogenous) individual performance and latent (endogenous) organizational performance at one of automotive company in Indonesia. Denison's cultural organization model is used in this study which consists of mission, consistency, involvement and adaptability. Individual work performance refer to the task performance, contextual performance (individual), contextual performance (organization), adaptive performance and counterproductive work behavior. While organizational performance is based on the concept of a balance scorecard which consists of a financial perspective, a customer perspective, an internal business process perspective and a learning and growth perspective. The sample is 174 which is intended for all employees throughout and at all levels in the company. The results showed that organizational culture has a significant influence on individual performance and organizational performance, so that the company is having adequate capabilities in relation to the implementation of organizational culture within the company which has an impact on individual work performance that has the potential improvement to the organizational performance of a company to deal with the intense competition in the automotive industry in Indonesia.
\end{abstract}

Keywords: Organizational culture, individual work performance, organizational performance.

\section{Introduction}

Company performance is strongly influenced by organizational culture where organizational culture is the most important construct in build and maintain a company performance. Organizational culture can be interpreted as a form of collective benefit that is understood and actualized by individuals as a differentiator of organizations with other organizations [1]. The values of an organization that are applied intensely and are simultaneously inspired and expanded can make one organizational culture strong. Widespread of acceptance related to the perspective of the company which is believed to provide benefits to individuals will further increase their attachment to values that have a significant influence on individual work performance thus providing a good atmosphere within the organization. Individual work performance has a cumulative influence on the performance of a company 


\section{Literature Review}

\subsection{Organizational Culture}

Organizational culture is the most important construct in this research where organizational culture is expected to improve organizational performance. Organizational culture can be seen from patterns and perspectives that guide individuals in behaving and responding to things that happen within the organization. Implementation of organizational culture can be seen and assessed from the dimensions of organizational culture [2]. One dimension model that is popular and very widely used by researchers is Denison's model organizational culture.

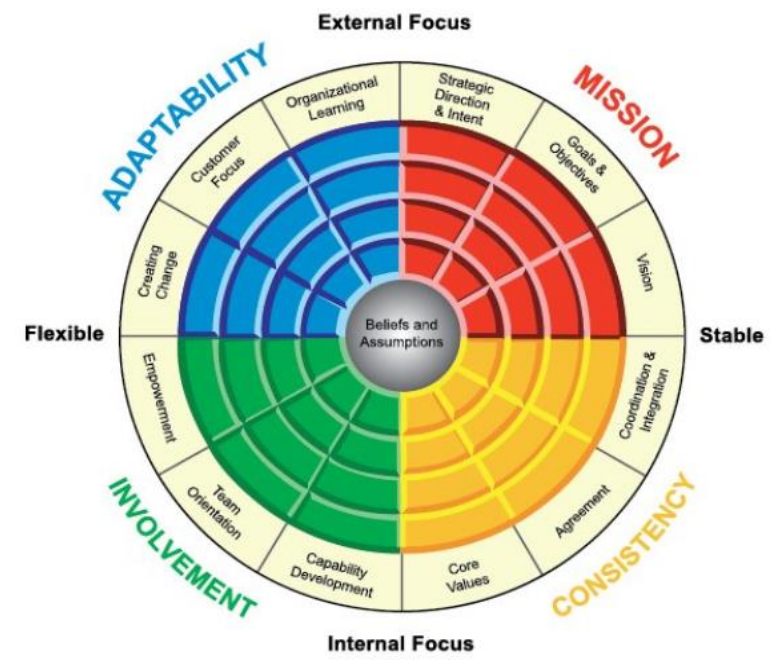

Fig. 1. Denison Model Organizational Culture Source: denisonconsulting.com

Based on the above picture regarding the organizational culture of Denison's model there are four cultural dimensions which can be explained as follows [3]:

a. Mission

The mission provides clear direction and goals that serve to determine actions that are appropriate for organizations and individuals within the organization. Mission can be measured by three indicators namely vision, goals and objectives, and strategic direction and intent.

b. Consistency

Is a source of stability and strong internal integration organizations are effective when consistency is well integrated. Consistency is measured by three core value such as indicators, agreement and coordination and integration.

c. Involvement

Effective organizations empower and involve individuals in organizations, build teams and develop individual abilities at all levels in the organization. Involvement can be measured by three indicators namely empowerment, team orientation and capability development. 


\section{d. Adaptability}

Organization adaptability translates the demands of the organizational environment into a variety of actions within organization. Adaptability can be measured by three indicators namely creating change, customer focus and organization learning.

\subsection{Individual Work Performance}

Individual work performance is closely related to organizational culture. Based on a systematic review [4] the dimensions of individual work performance are divided into several dimensions as follows:

a. Task Performance

Is the ability to perform core tasks.

b. Contextual Performance (Interpersonal \& Organization)

These are extra behaviors and actions beyond the main tasks that support the organization including the skills to carry out additional tasks, have initiatives, take on challenging tasks and develop knowledge and skills.

c. Adaptive Performance

It is the ability of individuals to be able to adapt to dynamic work situations. Successful adaptive performance means that individuals are able to handle and manage efficiently a form of uncertainty that cannot be predicted.

d. Counterproductive Work Behavior

Counterproductive work behavior shows contrast with behavior that is relevant to the organization's goals.

\subsection{Organizational Performance}

Organizational performance measurement uses refer to the balanced scorecard (BSC) approach, because the BSC emphasizes financial and nonfinancial measurements as a result of a top-down process regarding the mission of an organization. The following is an explanation of the four perspectives used in reference to the balance scorecard [5]:

a. Financial Perspective

Is the main measure related to crucial measurements that can measure the consequences of an action that has been carried out by the organization.

b. Customer Perspective

Is the level of customer satisfaction where satisfied customers are defined as customers who are loyal to the products produced by the company.

c. Internal Business Process Perspective

Focusing on the values expected by customers and stakeholders so that they must be innovative, always monitored and always improved.

d. Learning and Growth Process Perspectives

Paying attention to three main factors namely individuals, systems, and organizational procedures that provide prospects for the future 


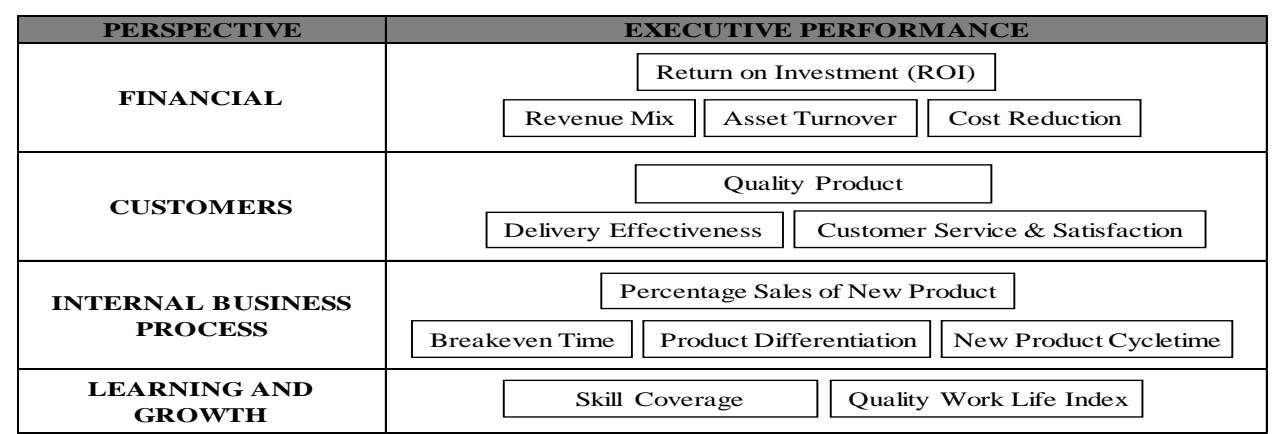

Fig. 2. Balance Scorecard Approach

\section{Methodology}

The approach used in this study is a quantitative approach that involves measurement and statistical analysis [6]. Research with a quantitative approach is positivist research with an emphasis on testing theory through measuring research variables. Referring to its purpose, this research is a type of explanatory research that seeks to answer the question of how and why a symptom occurs.

This research was conducted to see the influence between the variables studied. In this study, the variables that influence are organizational culture, while the variables that are affected are the individual work performce and organizational performance. The symptoms to be explained in this study are the influence of organizational culture on individual work performance and organizational performance.

The population as the subject of this study is employees at PT. Kramayudha Tiga Berlian Motors. Some members of the population can be used as samples that represent all representative members of the population [4]. The sampling design in this study refers to probability sampling. In determining the sample size, this study refers to the calculation formula with a population of 308 and a significance level of research 5\%, in this study determined a sample of 174 employees at PT. Kramayudha Tiga Berlian Motors, so that the data obtained is representative enough to use the structural equation modeling (SEM) technique. The sampling technique used in this study is proportional stratified random sampling, where grouping is based on the division of work at PT. Kramayudha Tiga Berlian Motors.

Table 1. Proportional Random Sampling Based on Divisions

\begin{tabular}{|c|c|c|c|c|c|}
\hline \multirow{2}{*}{ No } & \multirow{2}{*}{ Divisi } & \multicolumn{2}{|c|}{ Populasi } & \multicolumn{2}{|c|}{ Sampel } \\
\hline & & Jumlah & $\%$ & Jumlah & $\%$ \\
\hline 1 & $\mathrm{ADM} / \mathrm{HR}$ & 47 & $15 \%$ & 27 & $15 \%$ \\
\hline 2 & Sales \& marketing & 140 & $45 \%$ & 79 & $45 \%$ \\
\hline 3 & Production \& engineering & 79 & $26 \%$ & 45 & $26 \%$ \\
\hline 4 & Finance & 33 & $11 \%$ & 19 & $11 \%$ \\
\hline 5 & Product strategy & 9 & $3 \%$ & 5 & $3 \%$ \\
\hline & Jumlah & 308 & $100 \%$ & 174 & $100 \%$ \\
\hline
\end{tabular}

Source: Data processed by researcher (2019) 


\section{Result and Discussion}

\subsection{Validity and Realibility}

Before carrying out the analysis with structural equation modeling (SEM), the validity and reliability test were carried out on the research instrument. Validity test is needed in research to assess the instrument or set of measuring instruments whether it is appropriate to measure indicators in the variables to be examined in this study. In this study validity test with a significance level of $5 \%$ has been carried out, and it is produced that the instruments and indicators in this study are valid. The results of reliability testing on research instruments show that the research instruments for three variables are: organizational culture, individual work performance and organizational performance is valid and reliable.

\subsection{Analisis Structural Equation Modelling (SEM)}

Data processing at the full stage of the Structural Equation Modeling model is carried out by conformity testing and statistical tests related to latent variable organizational culture (Budorg), Individual Work Performance (Perfind) and Organizational Performance (Kinorg). Furthermore, the results of data processing for full analysis of the Structural Equation Modeling (Estimate) model are shown in the figure below:

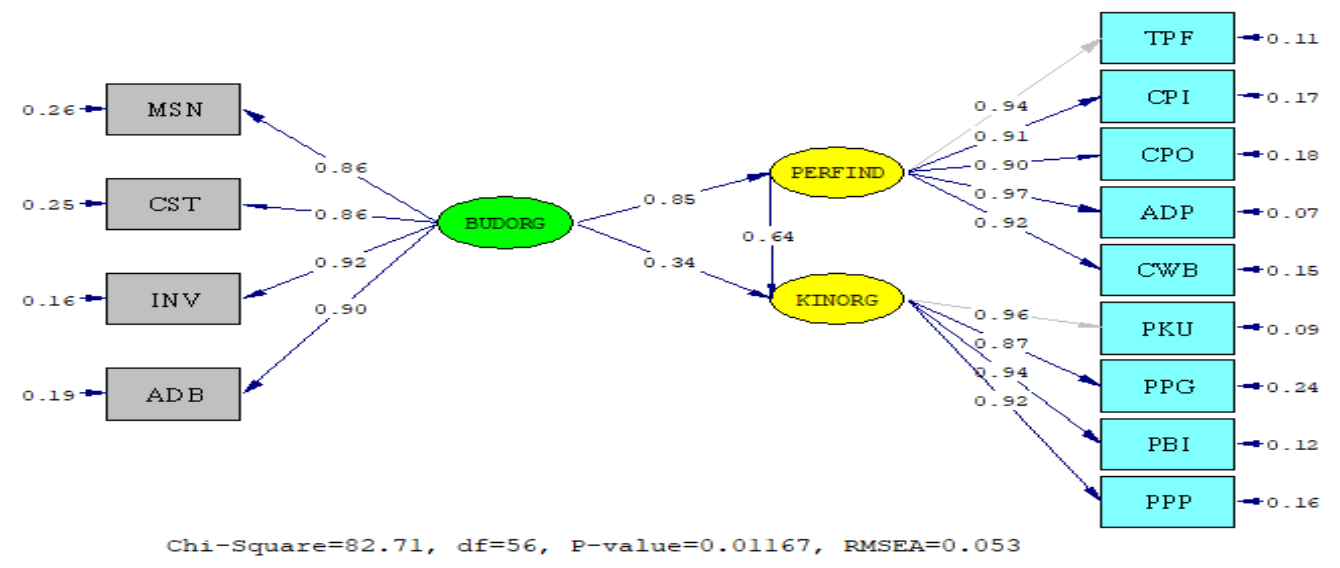

Fig. 3. Full Model Structural Equation Modeling (Standardized)

Source: Data processed by researcher (2019)

The following is a summary of the value of loading factors, $t$-value, $p$-value and RMSEA based on the results of research data processing with Structural Equation Modeling analysis tools.

Table 2. Structural Equations Full Model SEM (Direct Effect)

\begin{tabular}{lcccc}
\hline Path & Loading Factor $(>0,5)$ & $\begin{array}{c}\text { t-value } \\
(>1,96)\end{array}$ & $\begin{array}{c}\text { p-value } \\
(<0,05)\end{array}$ & $\begin{array}{c}\text { RMSEA } \\
(\leq 0,08)\end{array}$ \\
\hline Budorg $\rightarrow$ Perfind & 0,85 & 12,90 & 0,01 & 0,05 \\
Perfind $\rightarrow$ Kinorg & 0,64 & 9,39 & 0,01 & 0,05 \\
Budorg $\rightarrow$ Kinorg & 0,34 & 4,95 & 0,01 & 0,05 \\
\hline
\end{tabular}

Source: Data processed by researcher (2019) 
Table 3. Structural Equations Full Model SEM (Indirect Effect)

\begin{tabular}{|c|c|c|c|c|}
\hline Path & $\begin{array}{c}\text { Loading } \\
\text { Factor } \\
(>0,5)\end{array}$ & $\begin{array}{l}\text { t-value } \\
(>1,96)\end{array}$ & $\begin{array}{l}\text { p-value } \\
(<0,05)\end{array}$ & $\begin{array}{l}\text { RMSEA } \\
(\leq 0,08)\end{array}$ \\
\hline $\begin{array}{l}\text { Budorg } \rightarrow \text { Kinorg } \\
\text { (Through Perfind) }\end{array}$ & 0,55 & 8,08 & 0,01 & 0,05 \\
\hline \multicolumn{5}{|c|}{ Source: Data processed by researcher (2019) } \\
\hline Path & $\begin{array}{c}\text { Loading Factor } \\
(>0,5)\end{array}$ & $\begin{array}{l}\text { t-value } \\
(>1,96)\end{array}$ & $\begin{array}{l}\text { p-value } \\
(<0,05)\end{array}$ & $\begin{array}{c}\text { RMSEA } \\
(\leq 0,08)\end{array}$ \\
\hline Budorg $\rightarrow$ Perfind & 0,85 & 12,90 & 0,01 & 0,05 \\
\hline Perfind $\rightarrow$ Kinorg & 0,64 & 9,39 & 0,01 & 0,05 \\
\hline $\begin{array}{l}\text { Budorg } \rightarrow \text { Kinorg } \\
(\text { Direct }+ \text { Indirect })\end{array}$ & 0,88 & 13,80 & 0,01 & 0,05 \\
\hline
\end{tabular}

Source: Data processed by researcher (2019)

The process results can be seen from the output in the table above regarding loading factors from each path, the value of $t$-value, the value of $p$-value and also the value of RMSEA which can give an illustration of the results of structural equation modeling (SEM).

\section{Conclusion and Recommendation}

As a form of embodiment to provide answers to research questions to find out the influence of organizational culture on individual work performance and organizational performance it was found that organizational culture has a significant direct influence on individual work performance and individual work performance has a significant direct influence on organizational performance. While organizational culture has a direct and insignificant influence on organizational performance, but it has a significant effect if the individual's performance is the moderating variable. So that it is proven that the direct influence of organizational culture on organizational performance and the indirect influence of organizational culture through individual work performance as a moderating variable support each other to create high corporate performance.

Based on the variables tested in this study, the organizational culture that has been institutionalized and has been well implemented by the company. Caused by organizational culture that has been well institutionalized, the performance of individual work also has a good level of implementation, so that the effects of organizational culture that impact on individual work performance can have an effect on the performance of the company.

The good organizational culture and work performance of individuals must be maintained, cared for and enhanced with the spirit of kaizen (continuous improvement) that is in accordance with the needs and dynamics of the automotive industry in Indonesia to keep the company able to answer the needs and expectations of its customers can sustain and develop in order to increase marketshare to become an absolute market leader who focuses on giving satisfaction to its customers. 


\section{Reference}

[1] Schein, Organizational Culture and Leadership, 2nd Edition. San Francisco: JosseyBass, Inc, 1992.

[2] S. P. Robbins, Perilaku Organisasi. Buku 2. Jakarta: Salemba Empat, 2008.

[3] D. R. Denison and Sorenson, Corporate Culture and organizational Effectiveness. New York: John Wiley \& Sons., 2002.

[4] S. U. and B. R, Research Methods for Business. 6th Edition. New Jersey: John Wiley \& Sons, Inc.

[5] G. Hofstede and M. M., Cultures and Organizations 3rd edition. New York: McGraw Hill, 2010.

[6] W. G. Zikmund, Business Research Methods, 8th edition. South Western USA: Cengage Learning, 2010. 